Conclusion: Our study showed a high risk for misdiagnosis for patients with MCTD. Phenotype conversion was a very rare event. As a multi-organ disease, MCTD required prolonged (combined) immunosuppressive therapy to achieve remission. The establishment of an international registry with longitudinal data from observational multi-centre cohorts might represent a first step to address the many unmet needs of MCTD.

REFERENCES:

[1] Sharp GC. Diagnostic criteria for classification of MCTD. In: Kasukawa R Sharp GC, editors. Mixed connective tissue disease and anti-nuclear antibodies: proceedings of the International Symposium on Mixed Connective Tissue Disease and Anti-nuclear Antibodies, Tokyo, 29-30 August 1986. no. 719. Amsterdam: Elsevier Science Publishers B.V. (Biomedical Division); 1987. p. 23-30.

[2] Kasukawa R, Tojo T, Miyawaki S, Yoshida H, Tanimoto K, Nobunaga M, et al. Preliminary diagnostic criteria for classification of mixed connective tissue disease. In: Kasukawa R, Sharp GC, editors. Mixed connective tissue disease and anti-nuclear antibodies: proceedings of the International Symposium on Mixed Connective Tissue Disease and Anti-nuclear Antibodies, Tokyo, 29-30 August 1986. no. 719. Amsterdam: Elsevier Science Publishers B.V. (Biomedical Division); 1987. p. 41-7.

[3] Alarcón-Segovia D, Villarreal M. Classification and diagnostic criteria for mixed connective tissue disease. In: Kasukawa R, Sharp GC, editors. Mixed connective tissue disease and anti-nuclear antibodies: proceedings of the International Symposium on Mixed Connective Tissue Disease and Anti-nuclear Antibodies, Tokyo, 29-30 August 1986. no. 719. Amsterdam: Elsevier Science Publishers B.V. (Biomedical Division); 1987. p. 33-40.

Disclosure of Interests: Adrian Wanzenried: None declared, Alexandru Garaiman: None declared, Suzana Jordan: None declared, Oliver Distler Consultant of: O.D. had consultancy relationship and/or has received research funding from Abbvie, Actelion, Acceleron Pharma, Amgen, AnaMar, Baecon Discovery, Blade Therapeutics, Bayer, Boehringer Ingelheim, Catenion, Competitive Drug Development International Ltd, CSL Behring, ChemomAb, Curzion Pharmaceuticals, Ergonex, Ga-lapagos NV, Glenmark Pharmaceuticals, GSK, Inventiva, Italfarmaco, iQone, iQvia, Lilly, medac, Medscape, Mitsubishi Tanabe Pharma, MSD, Novartis, Pfizer, Roche, Sanofi, Target Bio Science and UCB in the area of potential treatments of scleroderma and its complications., Britta Maurer Consultant of: Boehringer-Ingelheim, Grant/research support from: AbbVie, Protagen, and Novartis Biomedical Research as well as congress support from Pfizer, Roche, Actelion, mepha, and MSD.

DOI: 10.1136/annrheumdis-2021-eular.545

\section{AB0412 LIPID PROFILE IN IIM PATIENTS AND ITS ASSOCIATION WITH DISEASE ACTIVITY, DURATION, AND GLUCOCORTICOID TREATMENT}

S. Oreska ${ }^{1,2}$, H. Štorkánová ${ }^{1,2}$, M. Špiritović ${ }^{1,3}$, B. Heřmánková ${ }^{3}$, M. Vrablik ${ }^{4}$, K. Pavelka ${ }^{1,2}$, L. Šenolt ${ }^{1,2}$, H. Mann ${ }^{1,2}$, J. Vencovský ${ }^{1,2}$, M. Tomčík ${ }^{1,2}{ }^{1}{ }^{1}$ Institute of Rheumatology, Department of Rheumatology, Prague, Czech Republic; ${ }^{2} 1 \mathrm{st}$ Faculty of Medicine, Charles University, Department of Rheumatology, Prague, Czech Republic; ${ }^{3}$ Faculty of Physical Education and Sport, Charles University, Department of Physiotherapy, Prague, Czech Republic; ${ }^{4}$ General University Hospital and 1st Faculty of Medicine, Charles University, 3rd Department of Internal Medicine, Prague, Czech Republic

Background: Systemic inflammation, limited mobility, and glucocorticoid treatment in idiopathic inflammatory myopathies (IIM) can have a negative impact on intermediate metabolic pathways, especially on lipid metabolism.

Objectives: The aim of this study was to assess the differences in the lipid profile of IIM patients and healthy controls ( $\mathrm{HC})$ and the association with disease-specific features.

Methods: 133 patients with IIM (106 females; mean age 60.3; disease duration 2.2 years; DM 47 / PM 41 / IMNM 45) and 133 age-/sex-matched HC (106 females, mean age 60.2) were included. Patients with DM and PM fulfilled the Bohan/ Peter criteria for PM/DM; patients with IMNM fulfilled the ENMC criteria. Levels of selected parameters of lipid metabolism were measured in sera. In IIM patients, disease activity, damage, and muscle involvement were evaluated (MITAX, MDI, MMT-8); comorbidities and current treatment were recorded. Data are presented as median.

Results: Several differences in disease activity, the dose of glucocorticoids, prevalence of comorbidities, and serum lipid levels were observed in IIM compared to $\mathrm{HC}$, and among the three subtypes of IIM; the most significant changes were observed in IMNM. All the differences in lipid profile between IIM and HC, as well as the correlations of lipid profile parameters with disease-specific features in IIM patients, are demonstrated in the table 1.

Conclusion: We have observed significant alterations in serum lipid parameters in our IIM patients compared to healthy age-/sex-matched individuals. Differences were also found among the three subtypes of IIM. These alterations were associated with laboratory parameters of disease activity and the current dose of corticosteroids.

Table 1. Lipidogram in IIM patients compared to healthy controls

\begin{tabular}{|c|c|c|c|c|c|c|}
\hline $\begin{array}{l}\text { Parameter of } \\
\text { lipidogram, } \\
\text { median }\end{array}$ & $\begin{array}{c}\text { IIM } \\
(n=133)\end{array}$ & $\begin{array}{c}\text { DM } \\
(n=47)\end{array}$ & $\begin{array}{c}\text { PM } \\
(n=41)\end{array}$ & $\begin{array}{l}\text { IMNM } \\
(n=45)\end{array}$ & $\begin{array}{l}\text { HC } \\
(n= \\
\text { 5) } 133)\end{array}$ & $\begin{array}{c}\text { p-value } \\
\text { IM-HC; DM-HC; } \\
\text { PM-HC; IMNM-HC }\end{array}$ \\
\hline TC (mmol/L); & 5.79 & 5.36 & 5.65 & 6.3 & 5.14 & $\begin{array}{r}<0.001 ; 0.135 \\
0.040 ;<0.001\end{array}$ \\
\hline $\mathrm{TG}(\mathrm{mmol} / \mathrm{L})$; & 2.02 & 1.91 & 1.88 & 2.27 & 1.28 & $\begin{array}{r}<0.001 ;<0.001 \\
0.002 ;<0.001\end{array}$ \\
\hline LDL-C (mmol/L); & 3.13 & 2.95 & 3.12 & 3.58 & 2.82 & $\begin{array}{c}0.005 ; 0.436 \\
0.131 ;<0.001\end{array}$ \\
\hline Apo-B (g/L); & 1.06 & 1.02 & 0.98 & 1.26 & 0.91 & $\begin{array}{r}<0.001 ; 0.160 \\
0.017 ;<0.001\end{array}$ \\
\hline Non-HDL-C (mmol/L); & 4.4 & 4.25 & 4.15 & 5.1 & 3.9 & $\begin{array}{r}<0.001 ; 0.262 ; \\
0.040 ;<0.001\end{array}$ \\
\hline Lp(a) (g/L); & 0.1 & 0.1 & 0.1 & 0.12 & 0.15 & $0.098 ; 0.733 ; 0.242 ; 0.032$ \\
\hline HDL-C (mmol/L); & 1.122 & 1.13 & 1.18 & 1.36 & 1.2 & $0.913 ; 0.917 ; 0.503 ; 0.928$ \\
\hline Apo-A (g/L); & 1.7 & 1.76 & 1.75 & 1.68 & 1.8 & $0.073 ; 0.782 ; 0.267 ; 0.025$ \\
\hline Al $(\log (T G / H D L-C) ;$ & 3.85 & 3.9 & 3.85 & 3.7 & 3.15 & $\mathbf{0 . 0 0 3} ; 0.425$ \\
\hline
\end{tabular}

Significant correlations of lipid profile parameters and disease-specific features in all IIM patients $(n=133)$

\begin{tabular}{|c|c|c|c|c|c|}
\hline $\begin{array}{l}\text { Correlated } \\
\text { parameters }\end{array}$ & $\begin{array}{l}\text { Spear- } \\
\text { man's r }\end{array}$ & $\begin{array}{l}\mathrm{p}- \\
\text { value }\end{array}$ & $\begin{array}{l}\text { Correlated } \\
\text { parameters }\end{array}$ & Spearman's $r$ & p-value \\
\hline \multirow{6}{*}{$\begin{array}{l}\text { TC: Disease duration; } \\
\text { LD; PED; Age; CK; } \\
\text { Myoglobin }\end{array}$} & -0.322 & $<0.001$ & non-HDL-C: & -0.303 & $<0.001$ \\
\hline & 0.343 & $<0.001$ & Disease duration; & 0.322 & $<0.001$ \\
\hline & 0.292 & $<0.001$ & LD; BMI; CK; & 0.202 & 0.027 \\
\hline & 0.193 & 0.027 & Myoglobin; PED & 0.214 & 0.015 \\
\hline & 0.198 & 0.025 & & 0.270 & 0.003 \\
\hline & 0.249 & 0.007 & & 0.275 & 0.002 \\
\hline \multirow{2}{*}{$\begin{array}{l}\text { TG: Disease duration; } \\
\text { PED; BMI }\end{array}$} & -0.326 & $<0.001$ & HDL-C: CRP & -0.230 & 0.010 \\
\hline & $\begin{array}{l}0.316 \\
0.271\end{array}$ & $\begin{array}{c}<0.001 \\
0.003\end{array}$ & & & \\
\hline \multirow{3}{*}{$\begin{array}{l}\text { LDL-: Disease } \\
\text { duration; LD; Age; } \\
\text { CK; Myoglobin; }\end{array}$} & -0.310 & $<0.001$ & Apo-A: CRP; CK; & $-0.293 ;-$ & $<0.001$ \\
\hline & 0.359 & $<0.001$ & Myoglobin & 0.214 & 0.016 \\
\hline & $\begin{array}{l}0.212 \\
0.257 \\
0.289\end{array}$ & $\begin{array}{l}0.015 \\
0.003 \\
0.002\end{array}$ & & $-0,258$ & 0.005 \\
\hline \multirow{9}{*}{$\begin{array}{l}\text { Apo-B: Disease } \\
\text { duration; LD; PED; } \\
\text { Age; BMI; MMT-8; } \\
\text { CK; Myoglobin; } \\
\text { Glycemia }\end{array}$} & -0.311 & $<0.001$ & Al: BMI & 0.209 & 0.021 \\
\hline & 0.348 & $<0.001$ & & & \\
\hline & 0.307 & $<0.001$ & & & \\
\hline & 0.220 & 0.012 & & & \\
\hline & 0.239 & 0.009 & & & \\
\hline & -0.214 & 0.017 & & & \\
\hline & 0.256 & 0.004 & & & \\
\hline & 0.307; & $<0.001$ & & & \\
\hline & 0.201 & 0.031 & & & \\
\hline
\end{tabular}

Acronyms: TC, total cholesterol; TG, triglycerides; LDL-C, low-density lipoprotein; Apo-B, apolipoprotein B; non-HDL-C, non-high-density lipoprotein (TC minus measured HDL-C); $\mathrm{Lp}(\mathrm{a})$, lipoprotein $\mathrm{A} ; \mathrm{HDL}-\mathrm{C}$, high-density lipoprotein; Apo-A, apolipoprotein A; Al, atherogenic index of plasma $=\log (T G / H D L-C)$; LD, lactate dehydrogenase; PED, current prednisolone equivalent dose; $\mathrm{CK}$, creatine kinase; BMI, body mass index; MMT-8, manual muscle testing-8; CRP, C-reactive protein

Acknowledgements: AZV NV18-01-00161A, MHCR-00023728, GAUK-312218 Disclosure of Interests: None declared

DOI: 10.1136/annrheumdis-2021-eular.816

\section{$\mathrm{AB} 0413$}

HIGH-RESOLUTION COMPUTED TOMOGRAPHY FOR THE SCREENING, RE-SCREENING AND FOLLOW-UP OF SYSTEMIC SCLEROSIS RELATED INTERSTITIAL LUNG DISEASE: RESULTS OF A EUSTAR-SCTC SURVEY

C. Bruni ${ }^{1,2}$, L. Chung ${ }^{3}$, A. M. Hoffmann-Vold ${ }^{4}$, S. Assassi ${ }^{5}$, A. Gabrielli ${ }^{6}$, D. Khanna ${ }^{7}$, E. Bernstein ${ }^{8}$, O. Distler ${ }^{2}$ on behalf of European Scleroderma Trials and Reserach (EUSTAR) group and Sclerodermia Clinical Trial Consortium (SCTC).. ${ }^{1}$ Careggi University Hospital, Experimental and Clinical Medicine, Division of Rheumatology, Firenze, Italy; ${ }^{2}$ University Hospital of Zürich, University of Zurich - Department of Rheumatology, Zürich, Switzerland; ${ }^{3}$ Stanford University School of Medicine and Palo Alto VA Health Care System, Department of Medicine and Dermatology, Division of Immunology and Rheumatology, Palo Alto (CA), United States of America; ${ }^{4}$ Oslo University hospital, Rheumatology, Oslo, Norway; ${ }^{5}$ The University of Texas Health Science Center at Houston, Division of Rheumatology, Houston, United States of America; ${ }^{6}$ Marche Polytechnic University Faculty of Medicine, Clinical and Molecular sciences, Ancona, Italy; ${ }^{7}$ University of Michigan, Scleroderma Program, Ann Arbor, United States of America; ${ }^{8}$ Columbia University Irving Medical Center, Division of Rheumatology, Department of Medicine, New York, United States of America 
Background: High-resolution computed tomography (HRCT) is the gold standard diagnostic test for Interstitial lung disease (ILD), a significant cause of morbidity and mortality in systemic sclerosis (SSc). Different algorithms have been proposed for the screening of SSc-ILD, including the use of pulmonary function tests (Forced Vital Capacity - FVC, Lung Diffusion of Carbone Monoxyde DLCO). A prior survey reported that $50-66 \%$ of general rheumatologists and SSc experts ordered HRCT for ILD screening in newly diagnosed SSc patients (1). Objectives: Given the recent availability of on-label treatment for SSc-ILD (2), the publication of consensus recommendations for the identification of SSc-ILD (3) and recent awareness programs for the use of HRCT to detect SSc-ILD, we aimed to re-evaluate the use of HRCT for screening, re-screening and follow-up of SSc-ILD. Methods: An invitation was sent to the European Scleroderma Trials and Research (EUSTAR) and Scleroderma Clinical Trials Consortium (SCTC) members, also advertised through social media. Answers were recorded between Nov $25^{\text {th }}$ and Dec $31^{\text {st }}$ 2020. Questions were asked on the use of chest HRCT at baseline, the re-screening of patients with a negative baseline HRCT and the follow-up of HRCT positive SSc-ILD patients. When HRCT was not routinely requested, additional details were collected about the parameters guiding its use. The results of the survey were tested for association with geographical origin, medical specialty, working environment, SSc referral institute and scientific group membership of the responders, using Chi-squared test.

Results: $205 / 630$ (32.5\%) physicians replied to the survey. Participants were widely distributed in terms of geographical origin (130 Europe, 23 Asia, 23 North America, 31 other continents), medical specialty (156 rheumatology, 21 internal medicine, 14 clinical immunology, 14 other), working environment (176 University Hospital, 12 community hospital, 17 other), SSc dedicated clinic (179 referral and 26 non-referral) and scientific group membership (98 EUSTAR, 42 SCTC, 42 EUSTAR and SCTC, 23 not declared).

At SSc diagnosis, $95.7 \%$ of responders would perform HRCT: $66.7 \%$ as routine screening for ILD $(67,4 \%$ of SSc referral and $62 \%$ for non-referral physicians) and $29 \%$ for diagnostic purposes (among the latter, if crackles on auscultation - $92.5 \%, \mathrm{FVC}<80 \%$ predicted $-86.6 \%, F \mathrm{FV} \pm \mathrm{DLCO}$ relative decline reaching the current definition of ILD progression, $86.6 \%$ or dyspnea at rest/exercise $-85.1 / 83.3 \%$ )

During follow-up, $78.8 \%$ of responders would repeat an HRCT in baseline negative cases: $20.3 \%$ as a yearly routine screening and $64.5 \%$ for diagnostic aims (decision on the latter group was more frequently driven by $\mathrm{FVC} \pm \mathrm{DLCO}$ relative decline indicative of ILD progression- $90.6 \%$, new onset or worsening of dyspnoea at rest/exercise $-80.5 / 86.6 \%$, new onset or worsening of lung crackles on auscultation $-82.6 \%$ )

Finally, $94.5 \%$ of responders would repeat a chest HRCT after SSc-ILD diagnosis: $36.8 \%$ as a yearly routine and $56.7 \%$ according to clinical evaluation (driven by new $F V C \pm$ DLCO relative decline based ILD progression $-90.8 \%$, new onset or worsening of dyspnoea at rest/exercise $-83.2 / 81.7 \% ; 5.2 \%$ to evaluate treatment effects). We found no difference in the distribution of answers among groups.

Conclusion: The use of baseline HRCT for the screening of SSc-ILD has slightly increased in non-referral and remained stable in referral centers compared to previous surveys, indicating that the implementation of guidelines might be successful and awareness programs should be continued. In addition, we provide new data on use of HRCT in re-screening and follow-up. The development of validated algorithms to further support the appropriate application of HRCT at follow-up is highly needed.

REFERENCES:

[1] Bernstein EJ et al. Arthritis Rheumatol. 2018 Jun;70(6):971-972.

[2] Distler O et al. N Engl J Med. 2019 Jun 27;380(26):2518-2528.

[3] Hoffmann-Vold AM et al. The Lancet Rheumatology, Volume 2, Issue 2, e71 - e83.

Disclosure of Interests: Cosimo Bruni Speakers bureau: Actelion, Consultant of: Eli Lilly, Grant/research support from: Foundation for Research in Rheumatology (FOREUM), Gruppo Italiano Lotta alla Sclerodermia (GILS), Fondazione Italiana per la Ricerca sull'Artrite (FIRA), New Horizon Fellowship, European Sclerodermia Trial and Reserach (EUSTAR) Group., Lorinda Chung Consultant of: Boehringer Ingelheim, Eicos, Mitsubishi Tanabe, Reata., Anna-Maria Hoffmann-Vold Consultant of: Actelion, ARXX therapeutics, Bayer, Boehringer-Ingelheim, Medscape, MSD, Lilly, Roche, Shervin Assassi Speakers bureau: Integrity Continuing Education, Consultant of: Boehringer Ingelheim, Novartis, and Corbus, Armando Gabrielli: None declared, Dinesh Khanna Consultant of: Acceleron, Actelion, Abbvie, Amgen, Bayer, Boehringer Ingelheim, CSL Behring, Corbus, Gilead, Galapagos, Genentech/Roche, GSK, Horizon, Merck, Mitsubishi Tanabe Pharma, Sanofi-Aventis, and United Therapeutics Leadership, Grant/research support from: NIH, Immune Tolerance Network, Bayer, BMS, Horizon, Pfizer, Employee of: Equity position - Chief Medical Officer, Eicos Sciences, Inc., Elana Bernstein Consultant of: Boehringer Ingelheim, Oliver Distler Consultant of: Abbvie, Acceleron Pharma, Amgen, AnaMar, Arxx Therapeutics, Baecon Discovery, Blade Therapeutics, Bayer, Boehringer Ingelheim, ChemomAb, Corbus Pharmaceuticals, CSL Behring, Galapagos NV, Glenmark Pharmaceuticals, GSK, Horizon (Curzion) Pharmaceuticals, Inventiva, iQvia, Italfarmaco, iQone, Kymera Therapeutics, Lilly, Medac, Medscape, Mitsubishi
Tanabe Pharma, MSD, Novartis, Pfizer, Roche, Sanofi, Serodapharm, Topadur, Target Bioscience and UCB., Grant/research support from: Abbvie, Acceleron Pharma Amgen, AnaMar, Arxx Therapeutics, Baecon Discovery, Blade Therapeutics, Bayer Boehringer Ingelheim, ChemomAb, Corbus Pharmaceuticals, CSL Behring, Galapagos NV, Glenmark Pharmaceuticals, GSK, Horizon (Curzion) Pharmaceuticals Inventiva, iQvia, Italfarmaco, iQone, Kymera Therapeutics, Lilly, Medac, Medscape Mitsubishi Tanabe Pharma, MSD, Novartis, Pfizer, Roche, Sanofi, Serodapharm, Topadur, Target Bioscience and UCB. Patent issued "mir-29 for the treatment of systemic sclerosis" (US8247389, EP2331143).

DOI: 10.1136/annrheumdis-2021-eular.849

\begin{tabular}{|l|l|}
\hline AB0414 & CROSS-CULTURAL ADAPTATION, CONVERGENT \\
& VALIDITY, AND RELIABILITY OF THE TURKISH \\
& VERSION OF THE COCHIN 17-ITEM SCLERODERMA \\
& FUNCTIONAL SCALE
\end{tabular}

N. G. Tore ${ }^{1}$, D. Oskay ${ }^{1}$, A. Avanoglu Guler ${ }^{2}$, A. Tufan ${ }^{2} .{ }^{1}$ Gazi University, Physiotherapy and Rehabilitation, Ankara, Turkey; ${ }^{2}$ Gazi University, Internal Medicine, Ankara, Turkey

Background: The Cochin 17-item Scleroderma Functional (CSF-17) Scale is a patient-reported outcome measure evaluating activities and participation in patients with systemic sclerosis (SSc).

Objectives: The aim of the present study was to translate and cross-culturally adapt the CSF-17 into the Turkish language and investigate its convergent validity and reliability in Turkish-speaking patients with SSc.

Methods: The CSF-17 was cross-culturally adapted according to Beaton's guideline. Participants completed CSF-17 Scale, Scleroderma Health Assessment Questionnaire (SHAQ), Short Form-12 (SF-12) Health Survey and Hospital Anxiety and Depression Scale (HADS). Internal consistency and test-retest reliability were determined interpreting Cronbach's alpha and Intraclass Correlation Coefficient (ICC) values, respectively. Convergent validity was tested using Pearson's correlation coefficient.

Results: Fifty-six patients with SSc were enrolled in the study. Cronbach's alpha and ICC values of the CSF-17 total score were found to be as 0.963 and 0.958 respectively, indicating excellent reliability. As for the convergent validity, it was determined that CSF-17 total score has a good correlation with SHAQ. Correlations of subscales of CSF-17 with subscales of SF-12 and HADS ranged from poor to moderate (Table 1).

Conclusion: Tukish version of CSF-17 met the set criteria of reliability and convergent validity. According to the results of the analysis, it was concluded that the Turkish version of the CSF-17 is a reliable and valid tool for Turkish-speaking SSc patients. REFERENCES:

[1] Daste C, Abdoul H, Foissac F et al. Development of a new patient-reported outcome measure to assess activities and participation in people with systemic sclerosis: the Cochin 17-item Scleroderma Functional scale. British Journal of Dermatology 2020; 183:710-718

[2] Beaton DE, Bombardier C, Guillemin F et al. Guidelines for the process of cross-cultural adaptation of self-report measures. Spine 2000;25(24):3186-3191.

[3] Karadag DT, Karakas F, Tekeoglu S et al. Validation of Turkish version of the Scleroderma Health Assessment Questionnaire. Clin Rheumatol, 2019,38(7):1917-1923.

[4] Ware Jr J, Kosinski M, Keller SD. A 12-Item Short-Form Health Survey: construction of scales and preliminary tests of reliability and validity. Med. Care, 1996,34:220-233.

[5] Zigmond A, Snaith R. The hospital anxiety and depression scale. Acta Psychiatr Scand, 1983,67:361-370.

[6] Terwee CB, Bot SD, de Boer MR et al. Quality criteria were proposed for measurement properties of health status questionnaires. J Clin Epidemiol, 2007,60:34-42

Table 1. Convergent validity of the CSF-17

\begin{tabular}{lccc}
\hline Scales & & CSF-17 & \\
\hline & Section A & Section B & Total \\
\hline SHAQ & $0.680^{\star \star}$ & $0.640^{\star \star}$ & $0.702^{\star *}$ \\
HADS-A & $0.405^{\star}$ & $0.472^{\star \star}$ & \\
HADS-D & $0.460^{\star *}$ & $0.605^{\star *}$ & \\
SF-12 MCS & $-0.482^{\star *}$ & $-0.491^{\star \star}$ & \\
SF-12 PCS & $-0.745^{\star *}$ & $-0.700^{\star *}$ &
\end{tabular}

CSF-17: Cochin 17-item Scleroderma Functional scale, SHAQ: Scleroderma Health Assessment Questionnaire, HADS-A: Hospital Anxiety and Depression Scale-Anxiety, HADS-D: Hospital Anxiety and Depression Scale-Depression, SF 12 MCS: Short Form-12 Mental Component Score, SF-12 PSC: Short Form-12 Physical Component Score. ${ }^{*} \mathrm{p}<0.05,{ }^{* *} \mathrm{p}<0.001$

Disclosure of Interests: None declared

DOI: 10.1136/annrheumdis-2021-eular.865 